\title{
PRILOG KLASIFIKACIJI TALA HRVATSKE - TLA URBANIH, INDUSTRIJSKIH I VOJNIH PROSTORA
}

\author{
CONTRIBUTION TO SOIL CLASSIFICATION OF CROATIA \\ - SOIL IN URBAN, INDUSTRIAL AND MILITARY AREA
}

\section{S. Husnjak, A. Špoljar}

\section{SAŽETAK}

U posljednje vrijeme u Hrvatskoj sve se više istražuju tla urbanih, industrijskih i vojnih prostora. S obzirom da urbani stanovnici provode znatan dio vremena na tim tlima, njihove značajke postale su iznimno bitne pa ih je nužno poznavati i uvažavati, naročito s aspekta potencijalnog onečišćenja i mogućeg štetnog utjecaja na zdravlje ljudi i životinja. Pri tome se postavlja pitanje njihove klasifikacije, s obzirom da se do nedavno u postojećim klasifikacijskim sustavima Republike Hrvatske takvim tlima nije pridavala značajnija pozornost. Cilj ovog rada je predložiti način razvrstavanja tala u urbanim, industrijskim i vojnim prostorima, uvažavajući pri tome postojeću strukturu klasifikacije tala Hrvatske (Husnjak, 2014.). Za izradu ovoga rada korišteni su postojeći podaci istraživanja tala u urbanim, industrijskim i vojnim prostorima Republike Hrvatske, temeljem čega su utvrđene značajke tih tala. Sva tla unutar navedenih prostora, predlaže se razvrstati u skupinu prirodnih, antropogenih ili tehnogenih i tehničkih antropogenih tala. Prirodna tla nastala su u skladu s pedogenetskim čimbenicima i procesima, dok su antropogena tla meliorirana prirodna tla isključivo u funkciji poljoprivredne proizvodnje. Ova tla bi trebalo razvrstavati prema spomenutoj klasifikaciji tala Hrvatske. Tehnogena i tehnička antropogena tla su novonastala tla isključivo zbog intenzivne tehnološke i tehničke djelatnosti čovjeka izvan poljoprivrede. Predlaže ih se razvrstati u red terestričkih tala, odnosno u razred tehnogenih ili u razred tehničkih tala. U razred tehnogenih tala, pripadaju uz tla deponija $i$ tla flotacijskih materijala, još dva nova tipa tla: tlo industrijskog kompleksa i tlo vojnog kompleksa. Spomenuta tla nerijetko čine tzv. „Brownfield“ zemljišta. U razred tehničkih tala predlaže se uvrstiti pet novih tipova tala: tlo parka, tlo igrališta, tlo zona za rekreaciju, tlo stambenog okoliša i tlo prometnog okoliša. Za navedene tipove tala daju se detaljni i jasni kriteriji za njihovu podjelu na niže pedosistematske jedinice.

Ključne riječi: tla urbanih, industrijskih i vojnih prostora; klasifikacija tala Hrvatske 
S. Husnjak i sur.: Prilog klasifikaciji tala Hrvatske - tla urbanih, industrijskih i vojnih prostora

\begin{abstract}
In recent years, soils of urban industrial and military areas have been increasingly researched in Croatia. Given that urban residents spend a considerable amount of time on these soils, soil characteristics have become extremely important. It is essential to know and appreciate those soils, especially in terms of potential contamination and possible harmful effects on human and animal health. This raises the question of those soils classification considering that, until recently, such soils have not received much attention in the existing Croatian soil classification systems. The aim of this paper is to propose a method of soil classification in urban, industrial and military areas, respecting the existing structure of soil classification of Croatia (Husnjak, 2014). For the preparation of this paper, the existing soil survey data form urban areas, industrial and military complexes were used, on the basis of which the properties of these soils were determined. All soils within urban, industrial and military areas are suggested to be classified as natural or anthropogenic or technological and technical anthropogenic soils. Natural soils were formed according to pedogenetic factors and processes, while anthropogenic soils are meliorated natural soils only for the purpose of agricultural production. This soils are proposed to be classified according to the existing Croatian soil classification. Technological and technical soils are newly formed soils solely due to the intensive human activity outside of agriculture. It is proposed to classify those soils in the order of terrestrial soils, and in the classes of technogenic or technical soils. Also, in the class of technogenic soils, it is proposed to include two new soil types in addition to landfill and flotation materials: the soil of industrial complexes and the soil of military complexes. The mentioned soils often form so-called Brownfield land. Lastly, five new soil types are proposed to be included in the class of technical soils: park soils, playground soils, soils of recreation zone, residential environment soils and traffic environment soils. For these soil types, detailed and clear criteria are proposed for the separation into lower pedosystematic units.
\end{abstract}

Key words: soil of urban, industrial, and military areas; Soil classification of Croatia

\title{
UVOD
}

Kartiranje tala u Hrvatskoj do nedavno se odnosilo samo na područje agro - i šumskih ekosustava. U posljednjih nekoliko desetljeća, kako u svijetu tako i u Hrvatskoj, sve više se istražuju tla urbanih prostora. Naime, zbog velikog broja 
S. Husnjak i sur.: Prilog klasifikaciji tala Hrvatske - tla urbanih, industrijskih i vojnih prostora

stanovnika u ovim područjima, kao i činjenice da urbani stanovnici provode znatan dio vremena na urbanim tlima poput tala parkova i gradskih vrtova, trgova, igrališta i rekreacijskih područja, njihove značajke postale su iznimno bitne, pa ih je nužno poznavati i uvažavati, naročito $s$ aspekta potencijalnog onečišćenja i mogućeg štetnog utjecaja na zdravlje ljudi, posebno djece i životinja.

Poznato je da u urbanim prostorima veći dio tala predstavljaju novonastala tla čija je priroda postanka tehničke naravi, odnosno to su tla formirana isključivo od strane čovjeka („man made soils“ ili „human modified soils"). Pored toga, znatan dio tala mogu predstavljati još uvijek prisutna ,prirodna tla“, a to su tla nastala u skladu s konstelacijom prirodnih pedogenetskih čimbenika i procesa. Ova tla mogu biti u znatnijoj mjeri onečišćena pa ih je i iz tog razloga nužno u većoj mjeri istraživati.

Kako se do nedavno u postojećim klasifikacijskim sustavima tlima urbanih prostora nije pridavala gotovo nikakva pozornost, postojeći nacionalni sustavi danas se sve više nadograđuju. U tom su razdoblju izuzetak činila tipična tehnogena tla, s obzirom da im se pridavala određena pozornost. Međutim, udio ovih tala u urbanim prostorima je malen pa je i to razlog slabijeg interesa za njihovo kartiranje i razvrstavanje. Temeljem navedenoga, u nekim visoko industrijaliziranim državama već duže vrijeme provode se projekti kartiranja tala urbanih prostora (Naeth i sur. 2012.; Rossiter 2004.; Rossiter 2007.).

Slična situacija je i u Hrvatskoj. Naime, u ranije korištenim klasifikacijama tala Gračanina iz 1951., Neugebauera i sur. iz 1963., Kovačevića i sur. iz 1967. te u klasifikaciji Škorića i sur. iz 1985. i Husnjaka iz 2014. godine, tla urbanih prostora nisu detaljnije razmatrana. Razlog za to je prije svega u činjenici što su prilikom izrade pedoloških karata različitog mjerila urbana područja izdvajana kao intravilani i na njima nisu provođena pedološka istraživanja. Pored toga, površine koje ova tla zauzimaju su neznatne u odnosu na površinu zemljišta u poljoprivrednim i šumskim ekosustavima (Husnjak, 2014; Pernar 2017; Špoljar 2015.).

Tijekom posljednja dva desetljeća, i u Hrvatskoj se intenzivnije istražuju tla urbanih prostora (Husnjak 2011.; Husnjak i sur. 2012.; Husnjak i sur. 2017.; Kisić i sur. 2007.; Kisić 2018.; Miko i sur. 2011.; Namjesnik-Dejanović 1994.; Palinkaš i sur. 1996.; Romić i sur. 2000.; Romić i sur. 2002.; Romić i sur. 2017/2018.; Šorša 2014.). Tijekom izrade ovih istraživačkih projekata, uočen je nedostatak postojećih klasifikacijskih sustava, koji se prije svega odnose na nomenklaturu i s time u svezi na nemogućnost razvrstavanja tala u postojeći 
S. Husnjak i sur.: Prilog klasifikaciji tala Hrvatske - tla urbanih, industrijskih i vojnih prostora

klasifikacijski sustav. Zbog toga su pedosistematske jedinice urbanih prostora najčešće razvrstavane u razred tehnogenih tala i izdvajane na razini tipa tla kao deposoli (tla deponija), iako ova tla prema svojim značajkama i načinu postanka ne pripadaju uvijek ovoj pedosistematskoj jedinici.

Nepostojanje adekvatne nomenklature, odnosno definicija i naziva pedosistematskih jedinica nastalih pod jakim tehničkim utjecajem čovjeka u urbanim prostorima, nastojalo se na međunarodnoj razini riješiti formiranjem radne skupine „Soils of Urban, Industrial, Traffic and Mining Areas (SUITIMA)“ 1998. godine. Kako navode Rossiter i Burghardt (2003.) i Rossiter (2004.) tijekom izrade Svjetske referentne osnovice za tlo (World Reference Base - WRB klasifikacija) počelo se sustavno raditi i na razvrstavanju tala urbanih i industrijskih prostora. U WRB klasifikaciji uvodi se pojam tehnogena tla (engl. Technosols), koji se odnosi na tla čiji su postanak i značajke direktno ovisni o podrijetlu tehnogenih materijala. Ova tla sadrže predmete nastale ljudskom aktivnošću (artefakte) i/ili otpadni materijal.

U Hrvatskoj postoje veći industrijski i vojni prostori, smješteni na rubu ili potpuno izvan urbanog prostora, gdje mogu pokrivati veliku površinu. Unutar ovih prostora postanak većeg dijela tala je „tehnogene“ ili „tehničke“ naravi, a manji dio nastaje prirodnim pedogenetskim procesima. Ova tehnogena i tehnička tla, često su jako onečišćena različitim količinama opasnog otpada. Pored navedenog, skupinu tih tala obilježava i činjenica da su građena pretežno od tehnogenih ili građevinskih materijala s visokim udjelom opasnih tvari. Neki znanstvenici takva onečišćena tla svrstavaju u skupinu „Brownfield“ zemljišta (Adelaja i sur. 2010.; Alker i sur. 2000.; Kisić 2012.; Kisić 2018.; MarkiewiczPatkowska i sur. 2005.). Tehnogena i tehnička tla nalaze se i u urbanim prostorima unutar industrijskih područja, gdje većinom zauzimaju vrlo malu površinu. Upotreba tala u industrijskim i vojnim prostorima bez intervencije je najčešće vrlo ograničena jer su u znatnoj mjeri onečišćena. U ranije spomenutim klasifikacijama tala, kao i u klasifikaciji tala Hrvatske (Husnjak, 2014.), ona pripadaju razredu tehnogenih tala, a na razini tipa tla razvrstavaju se kao tla deponija.

\section{KORIŠTENI MATERIJALI}

Za izradu ovoga rada korišteni su postojeći podaci istraživanja tala u urbanim prostorima Republike Hrvatske (Romić i sur. 2017./2018.), kao i drugi relevantni podaci iz ekspertiza (Husnjak 2011.; Husnjak i sur. 2017.; Kisić i sur. 
S. Husnjak i sur.: Prilog klasifikaciji tala Hrvatske

- tla urbanih, industrijskih i vojnih prostora

2007.; Romić i sur. 2002.; Romić i sur. 2017./2018.), stručnih, znanstvenih radova i disertacija (Husnjak i sur. 2012.; Miko i sur. 2011.; Palinkaš i sur. 1996.; Romić i sur. 2000.; Šorša 2014.), te udžbenika u kojima se analiziraju tla urbanih prostora (Kisić 2012., Kisić 2018.; Špoljar 2011.). S obzirom da Hrvatska nema pravilnik o zaštiti urbanih prostora od onečišćenja, za razvrstavanje tala na nižoj taksonomskoj razini od tipa korišteni su kriteriji o onečišćenju pojedinim štetnim tvarima prema preporukama koje se daju u Priručniku za trajno motrenje tala Hrvatske (AZO, 2006.).

\section{KLASIFIKACIJA TALA U URBANIM, INDUSTRIJSKIM I VOJNIM PROSTORIMA}

Osnovna obilježja tala u urbanim prostorima

Tla u urbanim prostorima najčešće se povezuje s onečišćenjem u okolišu i ljudskim zdravljem (Craul, 1992.). Dosadašnja istraživanja su, zbog te činjenice, obuhvaćala uglavnom utvrđivanje moguće onečišćenosti ovih tala. U manjoj mjeri je vršena procjena stupanja „narušenosti“ prirodnih ili tehničkih tala nastalih pod utjecajem čovjeka (engl. „man made soils“). Bockheim (1974.) urbano tlo definira kao ono koje se ne koristi u poljoprivredi, a nastalo je pod dominantnim utjecajem čovjeka, miješanjem, zatrpavanjem ili onečišćenjem gradskih i prigradskih površina. Autor navodi kako dubina takvog tla treba biti najmanje $50 \mathrm{~cm}$. Prema Wong-u i sur. (2006.) naziv urbana tla odnosi se na tla nastala popunjavanjem nižih reljefnih formi otpadnim materijalom (engl. "made ground soils"). Neki znanstvenici u urbana tla ubrajaju sva tla koja zauzimaju urbane prostore (Norra 2006.; Scharenbroch i sur. 2005.). Međutim, kako se u urbanom prostoru nalaze vrlo raznolika tla, nije ih ispravno na razini tipa nazvati „urbanim tlima“, pa se predlaže naziv „tla urbanih prostora". U urbanim prostorima koji ne obuhvaćaju industrijske i vojne prostore, nalazimo tla koja se mogu svrstati u tri skupine:

\section{Prirodna tla}

Nalaze se u okruženju stambenog, rekreacijskog, prometnog, industrijskog i vojnog prostora. Nastala su pod utjecajem pedogenetskih čimbenika i procesa. Ova tla nisu bitno narušena i mogu se u slučaju postojanja interesa koristiti i u poljoprivrednoj proizvodnji. 
S. Husnjak i sur.: Prilog klasifikaciji tala Hrvatske

- tla urbanih, industrijskih i vojnih prostora

\section{Antropogena tla}

U urbanom prostoru moguće je, iako vrlo rijetko, javljanje i antropogenih tala. Izvorno su to bila prirodna tla kod kojih su primijenjeni melioracijski zahvati uređenja zemljišta radi podizanja razine plodnosti isključivo u funkciji poljoprivredne proizvodnje.

\section{Tehnička antropogena tla (pseudo prirodna tla)}

To su novonastala tla isključivo intenzivnom tehničkom antropogenizacijom $\mathrm{u}$ procesu urbanizacije prilikom uređenja ili gradnje parkova, igrališta, rekreacijskih zona, te stambenog i prometnog okoliša (Husnjak 2011.; Husnjak i sur. 2012.; Husnjak i sur. 2017.; Šorša 2014.). Zauzimaju dominantnu površinu u urbanom prostoru.

Ključni kriterij za ovakvu podjelu je način postanka tla i razina utjecaja čovjeka. Pri tome razina potencijalne onečišćenosti tla $i$ način njegova korištenja ne mora biti kriterij za izdvajanje novog razreda tala u urbanom prostoru. Međutim, ona može biti važna za izdvajanje nižih sistematskih jedinica na razini podtipova, varijeteta i formi. Osnovne značajke prirodnih i antropogenih tala $\mathrm{u}$ urbanim prostorima istovjetne su onima $\mathrm{u}$ prirodnim uvjetima izvan urbanog prostora pa se mogu razvrstavati prema klasifikaciji tala Hrvatske (Husnjak 2014.).

Kako je već istaknuto, tehnička antropogena (umjetnim putem stvorena) ili novonastala tla, stvorena su pod utjecajem čovjeka s konkretnim ciljem uređenja urbanog prostora za neku specifičnu namjenu, a koja nije u vezi s poljoprivrednom proizvodnjom. U ova tla pripadaju ona koja su nastala nanošenjem zemljišnog, građevinskog, industrijskog ili drugog materijala na postojeće prirodno tlo. Pri tome su vrlo često sanirane šire depresije ili manje udubine korištenjem različitih materijala izmiješanih s česticama tla. Osnovni razlog za izdvajanje ovih tala u zasebnu skupinu je njihovo namjensko korištenje (parkovi, igrališta, rekreacijska područja, te prometni i stambeni okoliš). Prevladavajući čimbenik postanka tehničkih ili novonastalih tala je ljudska aktivnost u procesu urbanizacije prostora.

Za razliku od prirodnih i antropogenih tala, ova tehnička tla često obilježava izuzetno velika horizontalna i vertikalnu varijabilnost, te znatan udio artefakata, odnosno predmeta nastalih ljudskom djelatnošću, Slike 1. i 2. 
S. Husnjak i sur.: Prilog klasifikaciji tala Hrvatske - tla urbanih, industrijskih i vojnih prostora

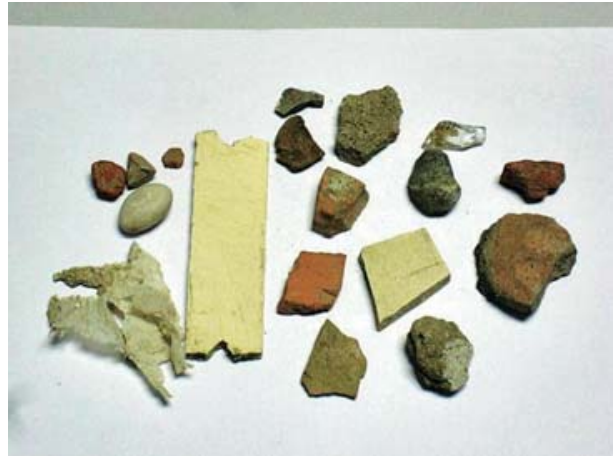

Slika 1. Različiti artefakti u pedološkom profilu grada Zagreba

Figure 1 The different artefacts within soil profile in Zagreb

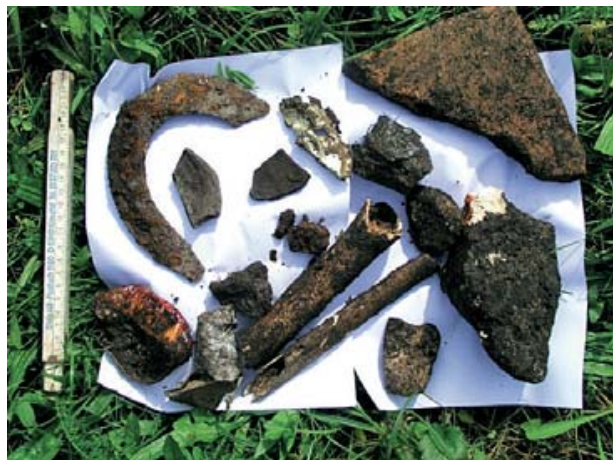

Slika 2. Različiti artefakti u pedološkom profilu grada Siska (izvor: Šorša, 2014.)

Figure 2 The different artefacts within soil profile in Sisak

U tablicama 1. i 2. prikazane su osnovne značajke tehničkih antropogenih tala koje proizlaze iz provedenih istraživanja u urbanim prostorima grada Zagreba i Siska (Kisić i sur. 2007; Husnjak 2011; Husnjak i sur. 2017; Romić i sur. 2000; Šorša 2014., Šorša i sur. 2017).

Tablica 1. Osnovne fizikalne značajke „tehničkih antropogenih" ili novonastalih tala u urbanom prostoru grada Zagreba i Siska

Table 1 Basic physical properties of „technical anthropogenic" or newly formed soils in the urban area of Zagreb and Sisak

\begin{tabular}{|l|l|}
\hline \multicolumn{1}{|c|}{ Značajke tla } & \multicolumn{1}{c|}{ Opis } \\
\hline $\begin{array}{l}\text { Dubina } \\
\text { slojeva }\end{array}$ & $\begin{array}{l}\text { Dubina pojedinih novonastalih slojeva vrlo je heterogena, kako unutar } \\
\text { pedološkog profila, tako i između njih, te varira od } 10 \text { do } 50 \mathrm{~cm} \text {. Ukupna } \\
\text { dubina novonastalih tehničkih slojeva ili novonastalog pedološkog profila } \\
\text { varira od oko } 60 \text { do više od } 100 \mathrm{~cm} .\end{array}$ \\
\hline Tekstura tla & $\begin{array}{l}\text { Tekstura novonastalih tehničkih slojeva pretežno je praškasto ilovasta. } \\
\text { Varira kako unutar pedološkog profila, tako i između različitih profila od } \\
\text { pjeskovito ilovaste, ilovaste do praškasto ilovaste. Kod slojeva koji sadrže } \\
\text { skelet, varira od slabo skeletoidne do skeletne. }\end{array}$ \\
\hline $\begin{array}{l}\text { Sadržaj } \\
\text { artefakata }\end{array}$ & $\begin{array}{l}\text { Sadržaj artefakata jako varira kako između slojeva profila tla, tako i između } \\
\text { pedoloških profila. Njihov sadržaj varira od } 5 \text { do } 70 \% \text {. Tala koja ne sadrže } \\
\text { artefakte gotovo da i nema. }\end{array}$ \\
\hline
\end{tabular}


S. Husnjak i sur.: Prilog klasifikaciji tala Hrvatske - tla urbanih, industrijskih i vojnih prostora

\begin{tabular}{|l|l|}
\hline $\begin{array}{l}\text { Vrsta } \\
\text { artefakata }\end{array}$ & $\begin{array}{l}\text { Najčešće su to usitnjeni komadi betona, asfalta, cigle, žbuke, keramike, } \\
\text { stijena ili kamena, ostaci najlona, plastike, stakla, kosti, metala, smeća i } \\
\text { stiropora. Vrsta artefakata između slojeva jednog pedološkog profila } \\
\text { najčešće jako varira. }\end{array}$ \\
\hline $\begin{array}{l}\text { Propusnost tla } \\
\text { za vodu }\end{array}$ & Propusnost tla za vodu pretežno je brza, a varira od vrlo brze do umjerene. \\
\hline $\begin{array}{l}\text { Stabilnost } \\
\text { mikroagregata }\end{array}$ & $\begin{array}{l}\text { Stabilnost strukturnih mikroagregata pretežno varira od nestabilnih do } \\
\text { malo stabilnih }\end{array}$ \\
\hline
\end{tabular}

Tablica 2. Osnovne kemijske značajke „tehničkih antropogenih“ ili novonastalih tala u urbanom prostoru grada Zagreba i Siska

Table 2 Basic chemical properties of „technical anthropogenic“ or newly formed soils in the urban area of Zagreb and Sisak

\begin{tabular}{|l|l|}
\hline \multicolumn{1}{|c|}{ Značajke tla } & \multicolumn{1}{|c|}{ Opis } \\
\hline Reakcija tla (pH) & $\begin{array}{l}\text { Reakcija tla „tehničkih“ ili novonastalih tala uglavnom je alkalna, } \\
\text { rjeđe neutralna. }\end{array}$ \\
\hline Sadržaj karbonata & Tla su pretežno osrednje do slabo karbonatna. \\
\hline Sadržaj humusa & $\begin{array}{l}\text { Kao posljedica uređenja zemljišta, površinski sloj tla je gotovo uvijek } \\
\text { znatno obogaćen organskom tvari tako da varira unutar raspona od } \\
\text { dobro do bogato humoznih tala. }\end{array}$ \\
\hline Sadržaj teških metala & $\begin{array}{l}\text { Koncentracije potencijalno toksičnih elemenata (PTE) pretežno su } \\
\text { manje od maksimalno dopuštenih koncentracija (MDK) koje su } \\
\text { preporučene Priručnikom za trajno motrenje tala Hrvatske (AZO, } \\
\text { 2006). Moguć je sadržaj pojedinog toksičnog elementa iznad MDK. }\end{array}$ \\
\hline $\begin{array}{l}\text { Policiklički aromatski } \\
\text { ugljikovodici (PAH) } \\
\text { i poliklorirani bifenili } \\
\text { (PCB) }\end{array}$ & $\begin{array}{l}\text { Koncentracije PAH-a i PCB-a iako su pretežno manje od maksimalno } \\
\text { preporučenih Priručnikom (AZO, 2006.), variraju iznad ili ispod } \\
\text { MDK. Često se pojedinačne tvari javljaju u koncentracijama većim od } \\
\text { MDK. }\end{array}$ \\
\hline
\end{tabular}

Osnovna obilježja tala u industrijskim i vojnim prostorima

Industrijski i vojni prostori zemljišta najčešće se nalaze na rubu, a manjim dijelom i unutar urbanog prostora. $\mathrm{U}$ tim prostorima uglavnom ne nalazimo prirodna tla već samo tehnogena antropogena tla. 
S. Husnjak i sur.: Prilog klasifikaciji tala Hrvatske - tla urbanih, industrijskih i vojnih prostora

\section{Tehnogena antropogena tla}

Tla industrijskih i vojnih prostora nastala su isključivo aktivnošću čovjeka. Često su onečišćena opasnim tvarima zbog čega se nerijetko nazivaju „brownfield“ zemljištima (Frantal i sur. 2013; Kisić 2012; Kisić 2018; Lange and McNeil 2004; Špirić 2015; Williams i Dair 2007.). Ova tla sadrže „umjetne“ materijale koji su nastali kao nusprodukt u industrijskim proizvodnim i vojnim postrojenjima i aktivnostima, a obilježava ih velika koncentracija opasnih tvari. U tablicama 3. i 4. prikazane su osnovne značajke tehnogenih antropogenih tala unutar industrijskih i vojnih prostora, utvrđene na temelju analize istraživačkih projekata i znanstvenih radova.

Tablica 3. Osnovne fizikalne značajke tehnogenih antropogenih ili novonastalih tala unutar industrijskih i vojnih prostora

Table 3 Basic physical properties of „technical anthropogenic“ or newly formed soils within industrial and military area

\begin{tabular}{|l|l|}
\hline \multicolumn{1}{|c|}{ Značajke tla } & \multicolumn{1}{|c|}{ Opis } \\
\hline Dubina slojeva & Dubina pojedinih novonastalih slojeva vrlo je heterogena. \\
\hline Tekstura tla & $\begin{array}{l}\text { Tekstura novonastalih tehničkih slojeva jako varira od praškaste do glinaste, } \\
\text { ili su to tvari bez izražene teksture. }\end{array}$ \\
\hline Priroda tvari & $\begin{array}{l}\text { Vrlo veliki udio u građi pojedinih slojeva čine „umjetni“ materijali } \\
\text { nastali ljudskom aktivnošću, kao što su nusprodukti u industriji ili } \\
\text { termoelektranama. Ovi „umjetni“ materijali mogu sadržati opasne tvari. }\end{array}$ \\
\hline
\end{tabular}

Tablica 4. Osnovne kemijske značajke tehnogenih antropogenih ili novonastalih tala unutar industrijskih i vojnih prostora

Table 4 Basic chemical properties of „technical anthropogenic" or newly formed soils within industrial and military area

\begin{tabular}{|l|l|}
\hline \multicolumn{1}{|c|}{ Značajke tla } & \multicolumn{1}{|c|}{ Opis } \\
\hline Reakcija tla $(\mathrm{pH})$ & Reakcija tla je uglavnom alkalna. \\
\hline Sadržaj humusa & $\begin{array}{l}\text { Uglavnom su vrlo slabe opskrbljenosti humusom jer su to } \\
\text { novonastali ,umjetni“ materijali. }\end{array}$ \\
\hline Sadržaj teških metala & $\begin{array}{l}\text { Koncentracije potencijalno toksičnih elemenata (PTE) uglavnom } \\
\text { su veće od maksimalno dopuštenih koncentracija (MDK) } \\
\text { preporučenih Priručnikom (AZO, 2006). }\end{array}$ \\
\hline $\begin{array}{l}\text { Policiklički aromatski } \\
\text { ugljikovodici (PAH) i } \\
\text { poliklorirani bifenili (PCB) }\end{array}$ & Koncentracije PAH-a i PCB-a pretežno su oko ili iznad MDK \\
\hline
\end{tabular}


S. Husnjak i sur.: Prilog klasifikaciji tala Hrvatske - tla urbanih, industrijskih i vojnih prostora

Prijedlog razvrstavanja tala u urbanim, industrijskim i vojnim prostorima Republike Hrvatske

U klasifikaciji tala Hrvatske, izdvojene su dvije skupine tala na čiji postanak dominantan utjecaj ima ljudska aktivnost: antropogena tla i tehnogena tla (Husnjak, 2014.). U antropogena tla pripadaju prirodna tla koja su osrednje do jako izmijenjena primjenom intenzivnih agro- i hidromelioracijskih zahvata radi podizanja razine njihove plodnosti. Ova tla su meliorirana isključivo u funkciji poljoprivredne proizvodnje. Na temelju značajki tla i primijenjenih melioracijskih mjera uređenja unutar pet redova tala izdvojeno je četrnaest tipova antropogenih tala. $U$ tehnogena tla razvrstavaju se ona tla koja su nastala kao rezultat industrijske i građevinske djelatnosti, pri čemu se zemljišni ili drugi materijali premještaju $\mathrm{s}$ mjesta njihovog nastanka na mjesto predviđeno za trajno odlaganje. Prema načinu odlaganja tehnogenih materijala, izdvojena su dva tipa tla: tla deponija (deposol) i tla flotacijskih materijala (flotisol).

Antropogena tla pretežno su povezana s poljoprivrednom proizvodnjom, a u inozemnoj pedološkoj literaturi spominju se i u kontekstu tala urbanih prostora. Prema nekim autorima, kako navodi Sobocka (2003.) tla u urbanim prostorima mogla bi se izdvajati kao urbana, poljoprivredna, industrijska, šumska i slično. Međutim, klasifikacija tala Hrvatske je genetsko-evolucijska i njena dopuna za tla u urbanom prostoru trebala bi se temeljiti na istim načelima. Kod toga je bitno razgraničiti dva ključna pojma: urbana tla i tla u urbanom prostoru. Termin „urbana tla“ je naziv tla koji može označavati njegovu tipološku pripadnost, a termin „tla u urbanom prostoru“ ukazuje na njegovu lokaciju i upućuje na činjenicu da u tom prostoru ima više različitih sistematskih jedinica tala. Da je ovakav pristup opravdan, ukazuje i činjenica da je Hrvatska relativno mala država, s malim brojem urbanih prostora i tlima u njima.

Problematika tala u industrijskim i vojnim prostorima nije identična situaciji u urbanim prostorima. Naime, industrijski i vojni prostori su uglavnom znatno manjih površina i pretežno homogeni po ostalim značajkama. Upravo zbog toga tehnogena antropogena ili novonastala tla unutar tih prostora treba razmatrati kao tla industrijskih $\mathrm{i}$ vojnih prostora. Temeljem navedenoga, može se predložiti sljedeći način razvrstavanja tala u urbanim, industrijskim i vojnim prostorima Republike Hrvatske, Tablice 5., 6. i 7. 
S. Husnjak i sur.: Prilog klasifikaciji tala Hrvatske - tla urbanih, industrijskih i vojnih prostora

Tablica 5. Prijedlog razvrstavanja tala u urbanim, industrijskim i vojnim prostorima Republike Hrvatske

Table 5 Soil classification proposal in urban, industrial and military areas in Republic of Croatia

\begin{tabular}{|c|c|c|c|c|c|}
\hline \multicolumn{6}{|c|}{ TLA U URBANOM, INDUSTRIJSKOM I VOJNOM PROSTORU } \\
\hline \multirow{2}{*}{$\begin{array}{l}\text { PRIRODNA } \\
\text { TLA* } \\
\text { Tla nastala u } \\
\text { skladu s } \\
\text { pedogenetskim } \\
\text { čimbenicima i } \\
\text { procesima bez } \\
\text { utjecaja čovjeka }\end{array}$} & \multirow{2}{*}{$\begin{array}{l}\text { ANTROPOGENA } \\
\text { TLA* } \\
\text { Tla nastala } \\
\text { djelomičnim utjecajem } \\
\text { čovjeka na način da su } \\
\text { kod prirodnih tala } \\
\text { primijenjeni } \\
\text { melioracijski zahvati } \\
\text { radi podizanja njihove } \\
\text { plodnosti isključivo u } \\
\text { funkciji poljoprivredne } \\
\text { proizvodnje (promjene } \\
\text { nastaju ,in situ“) }\end{array}$} & \multicolumn{4}{|c|}{$\begin{array}{l}\text { TEHNOGENA I TEHNIČKA } \\
\text { ANTROPOGENA TLA } \\
\text { (novonastala tla isključivo tehnološko } \\
\text { tehničkom aktivnošću čovjeka) }\end{array}$} \\
\hline & & \multicolumn{2}{|c|}{$\begin{array}{l}\text { Tehnogena tla } \\
\text { Tla nastala kao rezultat } \\
\text { tehnoloških procesa } \\
\text { uslijed industrijske, vojne } \\
\text { i komunalne djelatnosti } \\
\text { (znatan dio ovih tala čini } \\
\text { „Brownfield“ zemljišta) }\end{array}$} & \multicolumn{2}{|c|}{$\begin{array}{c}\text { Tehnička tla } \\
\text { Tla nastala izgradnjom } \\
\text { ili/i krajobraznim } \\
\text { uređenjem parkova, } \\
\text { igrališta, rekreacijskih } \\
\text { područja te okoliša } \\
\text { stambene i prometne } \\
\text { zone }\end{array}$} \\
\hline \multirow{3}{*}{$\begin{array}{c}\text { Prema } \\
\text { klasifikaciji tla } \\
\text { Hrvatske } \\
\text { (Husnjak, 2014) }\end{array}$} & \multirow{3}{*}{$\begin{array}{l}\text { Prema klasifikaciji } \\
\text { tlaHrvatske } \\
\text { (Husnjak, 2014) }\end{array}$} & \multirow{5}{*}{$\begin{array}{l}\text { Tipovi } \\
\text { tala }\end{array}$} & Tlo deponije & \multirow{5}{*}{$\begin{array}{l}\text { Tipovi } \\
\text { tala }\end{array}$} & Tlo parka \\
\hline & & & $\begin{array}{l}\text { Tlo flotacijskog } \\
\text { materijala }\end{array}$ & & $\begin{array}{l}\text { Tlo zona za } \\
\text { rekreaciju }\end{array}$ \\
\hline & & & \begin{tabular}{|l|} 
Tlo \\
industrijskog \\
kompleksa
\end{tabular} & & Tlo igrališsta \\
\hline \multirow{2}{*}{\multicolumn{2}{|c|}{$\begin{array}{l}\text { Napomena*: kod prirodnih i antropogenih } \\
\text { tala predlaže se na kraju naziva } \\
\text { pedosistematske jedinice navesti da se tlo } \\
\text { nalazi u urbanom, industrijskom ili } \\
\text { vojnom prostoru }\end{array}$}} & & \multirow{2}{*}{$\begin{array}{l}\text { Tlo vojnog } \\
\text { kompleksa }\end{array}$} & & \begin{tabular}{|l|} 
Tlo \\
stambenog \\
okoliša
\end{tabular} \\
\hline & & & & & \begin{tabular}{|l|} 
Tlo \\
prometnog \\
okoliša
\end{tabular} \\
\hline
\end{tabular}


S. Husnjak i sur.: Prilog klasifikaciji tala Hrvatske - tla urbanih, industrijskih i vojnih prostora

Tablica 6. Prijedlog kriterija za razvrstavanje tehnogenih tala na podtipove, varijetete i forme

Table 6 Proposal of the criteria for classification the technogenic soils on subtypes, varieties and forms

\begin{tabular}{|c|c|c|c|c|c|}
\hline \multicolumn{2}{|c|}{ Tlo deponija i flotacijskih materijala } & \multicolumn{3}{c|}{ Tlo industrijskog i vojnog kompleksa } \\
\hline Podtip & Varijetet & Forma & Podtip & Varijetet & Forma \\
\hline $\begin{array}{c}\text { Prema vrsti } \\
\text { tehnogenog } \\
\text { materijala }\end{array}$ & $\begin{array}{c}\text { Prema starosti } \\
\text { deponija i } \\
\text { dostignutom } \\
\text { stupnju razvoja }\end{array}$ & $\begin{array}{c}\text { Prema } \\
\text { onečišćenosti }\end{array}$ & $\begin{array}{c}\text { Prema } \\
\text { onečišćenosti }\end{array}$ & $\begin{array}{c}\text { Prema sadržaju } \\
\text { artefakata*, \% }\end{array}$ & $\begin{array}{c}\text { Prema } \\
\text { izvoru } \\
\text { onečišćenja }\end{array}$ \\
\hline \multicolumn{7}{|c|}{ Prema } \\
Prema klasifikaciji tla & $\begin{array}{c}\text { Priručniku za } \\
\text { trajno motrenje } \\
\text { tala Hrvatske } \\
\text { (AZO, 2006) }\end{array}$ & $\begin{array}{c}\text { Prema } \\
\text { Priručniku za } \\
\text { trajno motrenje } \\
\text { tala Hrvatske } \\
\text { (AZO, 2006) }\end{array}$ & $\begin{array}{c}20-50 \text { malo srednje } \\
50-75 \text { puno } \\
>75 \text { jako puno }\end{array}$ & $\begin{array}{c}\text { nafta, } \\
\text { eksplozivi, } \\
\text { otpad, itd. }\end{array}$ \\
\hline
\end{tabular}

* Predmeti nastali ljudskom djelatnošću

Tablica 7. Prijedlog kriterija za razvrstavanje tehničkih tala na podtipove, varijetete i forme

Table 7 Proposal of the criteria for classification the technical soils on subtypes, varieties and form

\begin{tabular}{|c|c|c|c|c|c|c|c|c|c|}
\hline \multirow{2}{*}{\multicolumn{2}{|c|}{$\begin{array}{c}\text { Podtipovi } \\
\text { Prema dubini } \\
\text { nanesenih slojeva } \\
\text { do prirodnog } \\
\text { horizonta, } \mathrm{cm}\end{array}$}} & \multicolumn{3}{|c|}{ Varijeteti } & \multicolumn{5}{|c|}{ Forme } \\
\hline & & \multicolumn{2}{|c|}{$\begin{array}{l}\text { Prema dostignutom } \\
\text { stupnju razvoja }\end{array}$} & $\begin{array}{c}\text { Prema } \\
\text { onečišćenosti }\end{array}$ & \multicolumn{2}{|c|}{$\begin{array}{l}\text { Prema sadržaju } \\
\text { artefakata*, \% }\end{array}$} & \multicolumn{2}{|c|}{$\begin{array}{l}\text { Prema sadržaju } \\
\text { skeleta, } \%\end{array}$} & $\begin{array}{l}\text { Prema } \\
\text { teksturi }\end{array}$ \\
\hline $0-25$ & $\begin{array}{l}\text { vrlo } \\
\text { plitko }\end{array}$ & & & & & & $<10$ & $\begin{array}{l}\text { slabo } \\
\text { skeletoidna }\end{array}$ & \\
\hline $25-50$ & plitko & mlađa tla & $\begin{array}{l}\text {-bez horizonta } \\
\text { (A) }\end{array}$ & $\begin{array}{c}\text { Prema } \\
\text { Priručniku }\end{array}$ & $<20$ & malo & $10-30$ & skeletoidna & \\
\hline $50-75$ & $\begin{array}{l}\text { Srednje } \\
\text { duboko }\end{array}$ & nerazvijena & -s horizontom & za trajno & $\begin{array}{l}20-50 \\
50-75\end{array}$ & $\begin{array}{l}\text { Srednje } \\
\text { puno }\end{array}$ & $30-50$ & skeletoidna & klasama \\
\hline $75-100$ & duboko & & (A) & motrenje & & jako & 7 & & (FAO, \\
\hline$>100$ & $\begin{array}{l}\text { vrlo } \\
\text { duboko }\end{array}$ & starija tla & $\begin{array}{l}\text {-s horizontom } \\
\text { A }\end{array}$ & $\begin{array}{l}\text { tala Hrvatske } \\
(A Z O, 2006)\end{array}$ & $>75$ & puno & $\begin{array}{r}70-90 \\
90-100\end{array}$ & $\begin{array}{l}\text { jako skeletna } \\
\text { potpuno } \\
\text { skeletna }\end{array}$ & 2006) \\
\hline
\end{tabular}

* Predmeti nastali ljudskom djelatnošću

Uvažavajući postojeću klasifikaciju tala Hrvatske, predlaže se da se u red terestričkih tala, odnosno unutar razreda „tehnogenih“ tala, uvrste još dva tipa tla: tlo industrijskog kompleksa i tlo vojnog kompleksa. Također se predlaže da se $u$ red terestričkih tala uvrsti još jedan razred naziva „tehnička tla“ sa sljedećim tipovima tala: tlo parka, tlo zona za rekreaciju, tlo igrališta, tlo stambenog okoliša i tlo prometnog okoliša. 
S. Husnjak i sur.: Prilog klasifikaciji tala Hrvatske - tla urbanih, industrijskih i vojnih prostora

Primjeri tehničkih tala

Slike 3. i 4. prikazuju pedološke profile tehničkih tala unutar urbanog prostora grada Zagreba i Siska
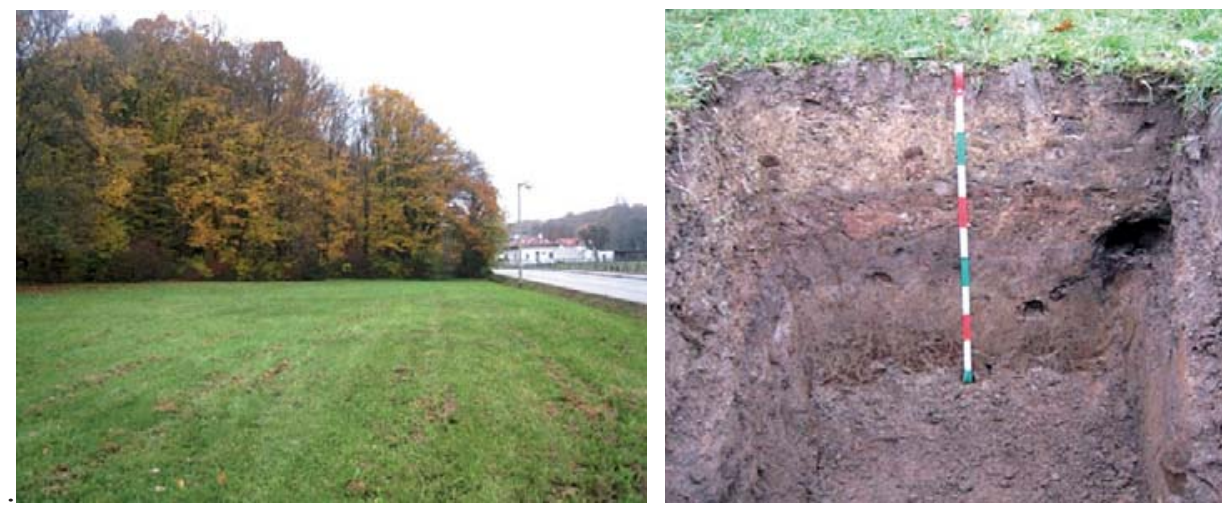

Slika 3. Krajolik i pedološki profil tla zone za rekreaciju

Lokacija: Spomen park Dotršćina, Zagreb, dubina nanesenih slojeva je $70 \mathrm{~cm}$

Figure 3 Landscape and pedological profile of the soil of the recreation zone Location: Memorial Park Dotršćina, Zagreb, depth of applied layers is $70 \mathrm{~cm}$
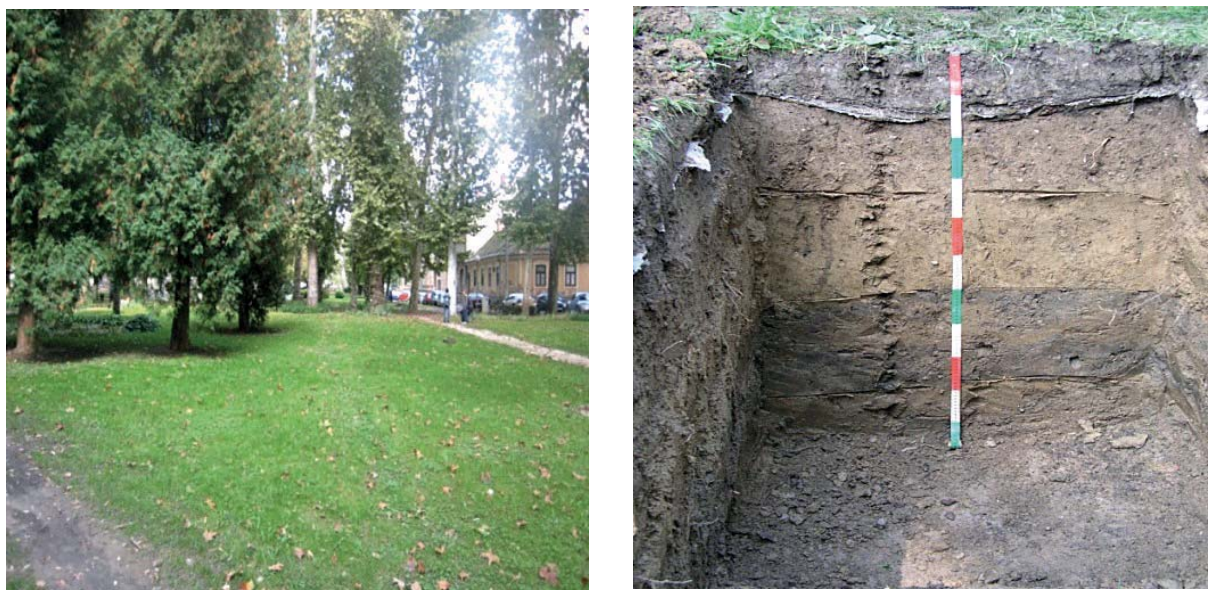

Slika 4. Krajolik i pedološki profil tla parka

Lokacija: Sisak, dubina nanesenih slojeva je $90 \mathrm{~cm}$

Figure 4 Landscape and pedological profile of the soil of the park

Location: Sisak, depth of the applied layers is $90 \mathrm{~cm}$ 
S. Husnjak i sur.: Prilog klasifikaciji tala Hrvatske - tla urbanih, industrijskih i vojnih prostora

Primjeri tehnogenih tala

Slike 5. i 6 . prikazuju pedološke profile tehnogenih tala koja nerijetko čine tzv. „Brownfield““ zemljišta.
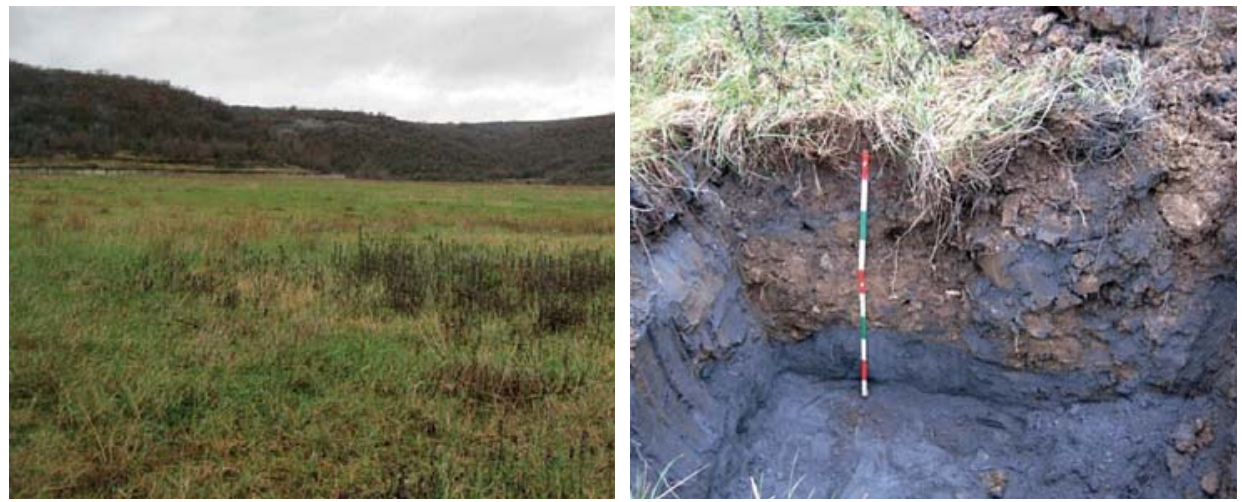

Slika 5. Krajolik i pedološki profil tla flotacijskih materijala unutar industrijskog kompleksa termoelektrane

Figure 5 Landscape and pedological profile of the soil of flotation materials within industrial complex the thermal power plant

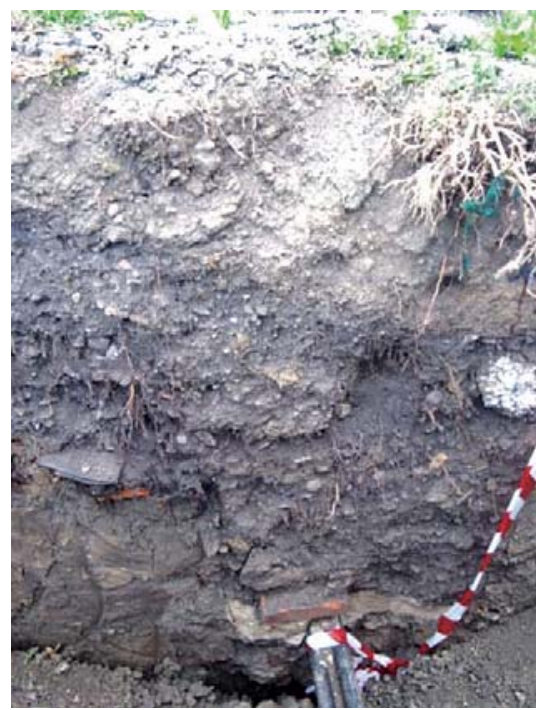

Slika 6. Pedološki profil tla industrijskog kompleksa (izvor: Kisić, 2018)

Figure 6 Pedological profil of the soil of industrial complex 
S. Husnjak i sur.: Prilog klasifikaciji tala Hrvatske

- tla urbanih, industrijskih i vojnih prostora

\section{ZAKLJUCAK}

Zbog mogućeg štetnog utjecaja tala u urbanim, industrijskim i vojnim prostorima na zdravlje ljudi i životinja, tijekom posljednja dva desetljeća izvršena su brojna istraživanja takvih tala. Temeljem navedenih istraživanja, odnosno postojećih literaturnih podataka, utvrđene su njihove osnovne značajke. Uvažavajući spomenute značajke tala kao i postojeću strukturu klasifikacije tala Hrvatske, predložen je način razvrstavanja tala u urbanim, industrijskim i vojnim prostorima.

$\mathrm{Na}$ prvoj razini predlaže se razvrstati navedena tla u skupinu prirodnih, antropogenih ili tehnogenih i tehničkih antropogenih tla. Prirodna i antropogena tla trebalo bi razvrstavati kao i dosad, odnosno prema klasifikaciji tala Hrvatske. Tehnogena i tehnička antropogena tla (ili novonastala tla zbog intenzivne ljudske tehnološke i tehničke djelatnosti), predlaže se svrstati u red terestričkih tala, te razvrstati u postojeći razred tehnogenih ili u novi razred tehničkih tala. U razred tehnogenih tala trebalo bi uključiti dva nova tipa tla: tlo industrijskog i tlo vojnog kompleksa, u inozemnoj literaturi poznata kao „Brownfield“ zemljišta. U novi razred tehničkih tala predlaže se svrstati pet novih tipova tala: tlo parka, tlo igrališta, tlo zona za rekreaciju, tlo stambenog okoliša i tlo prometnog okoliša. Za navedene nove tipove tala u radu su predloženi detaljni kriteriji za njihovu podjelu na niže pedosistematske jedinice.

\section{LITERATURA}

1. Adelaja, S., Shaw, J., Beyea, W., McKeown, J.D.C. (2010.): Renewable energy potential on brownfield sites: A case study of Michigan. Energy Policy. Volume 38, Issue 11, p 7021-7030.

2. Alker, S., Joy, V., Roberts, P., Smith, N. (2000.): The definition of Brownfield. Journal of Environmental Planning and Management Vol. 43, Iss. 1.

3. AZO (2006.): Priručnik za trajno motrenje tala Hrvatske, Agencija za zaštitu okoliša, Zagreb, 204 str.

4. Bockheim, J.G. (1974.): Nature and properties of highly disturbed urban soils, Philadelphia, Pennsylvania.- Paper presented before Div. S-5, Soil Sci. Soc. Am., Chicago, Illinois.

5. Craul, J.P. (1985.): A description of urban soils and their desired characteristics.- Annual conference of the Internat. Society of Arboriculture, in August of 1985, Milwaukee, USA. 
S. Husnjak i sur.: Prilog klasifikaciji tala Hrvatske - tla urbanih, industrijskih i vojnih prostora

6. Craul, J.P. (1992.): Urban soil in landscape design.- J. Wiley and Sons, New York, $385 \mathrm{p}$.

7. FAO (2006.): Guidelines for soil profile description $\left(4^{\text {th }}\right.$ ed.). Rome: Food and Agriculture Organisation of the United Nations, $97 \mathrm{pp}$

8. Frantál, B., Kunc, J., Nováková, E., Klusáček, P., Martinát, S., Osman, R. (2013.): Location matters! Exploring brownfields regeneration in a spatial context (case study of the South Moravian Region), Moravian Geographical Reports, Vol. 21, No. 2, p. 5-19.

9. Gračanin, M. (1951.): Pedologija. III dio - Sistematika tla. Školska knjiga, Zagreb, 298 str.

10. Husnjak, S., Rossiter, D.G., Hengl, T., Miloš, B. (2004.): Soil inventory and soil classification in Croatia: historical review, current activities, and future directions.- ISRIC Country Report, 17 p.

11. Husnjak, S. (2011.): Pedofizikalne i pedokemijske analize pedoloških jama u Sisku. Arhiva HGI-a, interno izviješće, Zagreb

12. Husnjak, S., Rubinic, V., Halamic, J., Šorša, A. \& Vrbek, B. (2012.): Characteristics and classification of urban soils in city of Sisak, Croatia.Eurosoil, 2012. $4^{\text {th }}$ International Congress of the ECSSS, 2-6 July 2012, Bary, Italy.

13. Husnjak, S. (2014.): Sistematika tala Hrvatske. Sveučilišni udžbenik. Hrvatska sveučilišna naklada, Zagreb, 368 str.

14. Husnjak, S., Jungić, D., Rubinić, V. (2017.): Značajke tala na lokacijama za organiziranje trajnog monitoringa tla $\mathrm{u}$ urbanom području grada Zagreba. Izvještaj je izrađen za potrebe projekta „Određivanje (uspostava monitoringa) kontaminacije tala za program Ekološka mreža grada Zagreba“. Sveučilište u Zagrebu Agronomski fakultet.

15. IUSS WORKING GROUP WRB (2014.): World reference base for soil resources 2014. World Soil Resources Reports. FAO, Rome, No. 106, 181 p.

16. Kisic, I., Bašic, F., Mesic, M., Zgorelec, Ž., Jurišic, A. \& Sajko, K. (2007): Elaborat trenutnog stanja onecišcenosti tala unutar kruga Rafinerije nafte Sisak.- Zavod za opću proizvodnju bilja Agronomskog fakulteta, Zagreb, 90 p.

17. Kisić, I. (2012.): Sanacija onečišćenog tla. Sveučilišni udžbenik. Sveučilište u Zagrebu Agronomski fakultet, $276 \mathrm{str}$.

18. Kisić, I. (2018.): Gradska poljoprivreda. Sveučilišni udžbenik. Sveučilište u Zagrebu Agronomski fakultet, 311 str. 
S. Husnjak i sur.: Prilog klasifikaciji tala Hrvatske - tla urbanih, industrijskih i vojnih prostora

19. Kovačević, P., Kalinić, M., Pavlić, V. (1967.): Detaljna klasifikacija tala i izrada pedološke karte Hrvatske Posavine mjerila 1.50.000. III: kongres JDPZ, zbornik radova, Zadar.

20. Lange, D., McNeil, S. (2004.): Brownfield Development: Tools for Stewardship, Journal of Urban Planning and development, 130, p. 109-116.

21. Markiewicz-Patkowska, J., Hursthouse, A., Przybyla-Kij, H. (2005.): The interaction of heavy metals with urban soils: sorption behaviour of $\mathrm{Cd}, \mathrm{CU}, \mathrm{Cr}$, $\mathrm{Pb}$ and $\mathrm{Zn}$ with a typical mixed brownfield deposit. Environment International 31, str. 513-521.

22. Miko, S., Šparica-Miko, M., Hasan, O.,Mesic, S., Ilijanic, N. (2011.): Geochemistry of kindergarten playground soils in Zagreb, Croatia.- In: Pertti Sarala, V. Juhani Ojala \& Marja-Leena Porsanger (eds.): Programme and Abstracts 25th International Applied Geochemistry Symposium 2011, 22-26 August 2011, Rovaniemi, Finland.

23. Naeth, M. A., Archibald, H. A., Nemirsky, C. L., Leskiw, L. A., Brierley, J. A., Bock, M. D., VandenBygaart, A. J., Chanasyk, D. S. (2012): Proposed classification for human modified soils in Canada: Anthroposolic order. Canadian Journal of Soil Science, 92:7-18.

24. Namjesnik-Dejanovic, K. (1994.): Distribucija teških metala u tlima grada Zagreba i njegove okolice. - Magistarski rad, Sveučilište u Zagrebu, Rudarskigeološki-naftni fakultet, Zagreb, 69 str.

25. Neugebauer, V., Čirić, M., Filipovski, G., Škorić, A., Živković, M. (1963.): Klasifikacija zemljišta Jugoslavije. Zemljište i biljka, Vol. XII, broj 1-3, Beograd.

26. Norra, S. (2006.): Urban Soil Science on the 18th WCSS. J Soils Sediments 6 (3); 189

27. Palinkaš, L., Namjesnik-Dejanović, K., MIko, S., Durn, G., Pirc, S. (1996.): Distribution of mercury, lead, and cadmium in Zagreb City Soils. U Environmental Xenobiotics. Ed. Richardson, M. Izd: Tayor and Francis, London. Str. 355-374

28. Pandžic, M. (2012.): Urbana geokemija: Distribucija teških metala sekvencijskim ekstrakcijskim frakcijama Rendzine na deposolu i Aluvijalnog livadskog tla grada Siska. Diplomski rad. Rudarsko-geološko-naftni fakultet, Sveučilište u Zagrebu, 121 str.

29. Pernar, N. (2017.): Tlo : nastanak, značajke, gospodarenje. Udžbenik, Sveučilište u Zagrebu Šumarski fakultet, 799 str. 
S. Husnjak i sur.: Prilog klasifikaciji tala Hrvatske - tla urbanih, industrijskih i vojnih prostora

30. Prša, L. (2011.): Urbana geokemija: Distribucija teških metala ekstrakcijskim frakcija deposola grada Siska. Diplomski rad. Rudarsko-geološko-naftni fakultet, Sveučilište u Zagrebu, 106 str.

31. Resulović, H., Čustović, H., Čengić, I. (2008.): Sistematika tla/zemljištanastanak, svojstva i plodnost. Poljoprivredno prehrambeni fakultet Univerziteta u Sarajevu, 231 str.

32. Romić, M., Romić, D., Mirošević, N. (2000.): Studija: Onečišćenost tala i trajno motrenje u Zagrebačkoj županiji. Sveučilište u Zagrebu, Agronomski fakultet, 76 str.

33. Romić, M. (2002.): Sadržaj, oblici i preraspodjela imisije teških kovina u poljoprivrednim tlima šireg područja Zagreba. Disertacija, Sveučilište u Zagrebu Agronomski fakultet, 219 str.

34. Romić, M., Bakić, H., Husnjak, S. i grupa autora (2017/2018): Određivanje (uspostava monitoringa) kontaminacije tala za program „Ekološka mreža grada Zagreba“. Sveučilište u Zagrebu Agronomski fakultet.

35. Rossiter, D.G., Burghardt, W. (2003.): Classification of urban and industrial soils in the World Reference Base for Soil Resources.- In: Morel, J.I. (ed.), SUITMA 2003. Nancy (F), Conference CD-ROM: 1028.pdf.

36. Rossiter, D.G. (2004.): Classification of urban and industrial soils in the World Reference Base for Soil Resources.- EUROSOIL 2004: 2nd European Soil Science Conference, Freiburg.

37. Rossiter, D. (2007.): Classification of Urban and Industrial Soils in the World Reference Base for Soil Resources. Journal of Soils and Sediments, Volume 7, Issue 2, pp 96-100.

38. Sobocka, J. (2003.): Urban soils vs anthropogenic soils, their differentiation and classification.- Paper presented at SUITMA 2003, Nancy, France, 3p.

39. Sobocka, J. (2008.): Position of Technosols in the Slovak Soil Classification System and their Correlation. Gruntoznalstvo. Vol 9 (2008.) No 3-4 (13). 177182.

40. Scharenbroch, B.C., Lloydc, J,E., Johnson-Maynard, J,L. (2005.): Distinguishing urban soils with physical, chemical, and biological properties. Pedobiologia 49, 283-296.

41. Škorić, A., Filipovski, G., Ćirić, M. (1985.): Klasifikacija zemljišta Jugoslavije. Akademija nauka i umjetnosti Bosne i Hercegovine, Sarajevo, 72 str. 
S. Husnjak i sur.: Prilog klasifikaciji tala Hrvatske - tla urbanih, industrijskih i vojnih prostora

42. Šorša, A. (2014.): Urbana geokemija potencijalno toksičnih elemenata u tlima grada Siska i njegove okolice. Disertacija, Sveučilište u Zagrebu Rudarsko geološko naftni fakultet, 295 str.

43. Šorša, A., Durn, G., Halamić, J., Husnjak, S., Garašić, V., Mileusnić, M. (2017.): Urban geochemistry: Sisak in Croatia, a long- lasting historical, urban and industrial city. Geochemuistry-exploration environment analysis 17, str. 159-168.

44. Špirić, A. (2015.): Prostorni kriteriji u urbanoj obnovi industrijskih Braunfild lokacija. Građevinar, br 67/9, str. 865-877.

45. Špoljar, A. (2011.): Onečišćenje okoliša. Udžbenik Visokog gospodarskog učilišta u Križevcima, 132 str.

46. Špoljar, A. (2015.): Pedologija. Udžbenik Visokog gospodarskog učilišta u Križevcima, 223 str.

47. Vršćaj, B., Kralj, T. (2017.): Chapter: Slovenian Soil Classification and WRB. In the Soils of Slovenia. World Soils Book Series, str. 61-75.

48. Williams, K., Dair, C. (2007.): A framework for assessing the sustainability of brownfield developments, Journal of Environmental Planning and Management, 50(1), p. 23-40.

49. Wong, C.S.C., Li, X., Thornton, I. (2006.): Urban environmental geochemistry of trace metals-review. Environmental pollution, 142, 1-16.

50. ***NN br. 71/2019: Pravilnik o zaštiti poljoprivrednog zemljišta od onečišćenja, Ministarstvo poljoprivrede RH.

Adrese autora - author's adress:

Prof. dr. sc. Stjepan Husnjak

e-mail: s.husnjak@agr.hr

Sveučilište u Zagrebu, Agronomski fakultet

Svetošimunska 25, 10000 Zagreb

Dr. sc. Andrija Špoljar, prof. v.š.

e-mail: aspoljar@vguk.hr

Visoko gospodarsko učilište u Križevcima

M. Demerca 1, 48260 Križevci

\section{Primljeno - received}

22.12.2019. 
S. Husnjak i sur.: Prilog klasifikaciji tala Hrvatske - tla urbanih, industrijskih i vojnih prostora 